\title{
QSAR STUDY OF INSECTICIDES OF PHTHALAMIDE DERIVATIVES USING MULTIPLE LINEAR REGRESSION AND ARTIFICIAL NEURAL NETWORK METHODS
}

\author{
Adi Syahputra ${ }^{1, *}$, Mudasir ${ }^{1,2}$, Nuryono $^{2}$, Anifuddin Aziz ${ }^{3}$, and Iqmal Tahir ${ }^{1,2}$ \\ ${ }^{1}$ Austrian-Indonesian Centre (AIC) for Computational Chemistry, Universitas Gadjah Mada, \\ Sekip Utara Yogyakarta 55281, Indonesia \\ ${ }^{2}$ Department of Chemistry, Faculty of Mathematics and Natural Sciences, Universitas Gadjah Mada, \\ Sekip Utara, Yogyakarta 55281, Indonesia \\ ${ }^{3}$ Computer Sciences Study Program, Faculty of Mathematics and Natural Sciences, Universitas Gadjah Mada, \\ Sekip Utara, Yogyakarta 55281, Indonesia
}

Received December 10, 2013; Accepted March 26, 2014

\begin{abstract}
Quantitative structure activity relationship (QSAR) for 21 insecticides of phthalamides containing hydrazone $(P C H)$ was studied using multiple linear regression (MLR), principle component regression (PCR) and artificial neural network $(A N N)$. Five descriptors were included in the model for MLR and ANN analysis, and five latent variables obtained from principle component analysis (PCA) were used in PCR analysis. Calculation of descriptors was performed using semi-empirical PM6 method. ANN analysis was found to be superior statistical technique compared to the other methods and gave a good correlation between descriptors and activity $\left(r^{2}=0.84\right)$. Based on the obtained model, we have successfully designed some new insecticides with higher predicted activity than those of previously synthesized compounds, e.g. 2-(decalinecarbamoyl)-5-chloro-N'-((5-methylthiophen-2-yl)methylene) benzohydrazide, 2-(decalinecarbamoyl)-5-chloro-N'-((thiophen-2-yl)-methylene) benzohydrazide and 2-(decaline carbamoyl)-N'-(4-fluorobenzylidene)-5-chlorobenzohydrazide with predicted $\log L C_{50}$ of 1.640, 1.672, and 1.769 respectively.
\end{abstract}

Keywords: QSAR; phathalamide; hydrazone; multiple linear regression; principle component regression; artificial neural network

\section{ABSTRAK}

Telah dilakukan kajian analisis Hubungan Kuantitatif Struktur Aktivitas (HKSA) insektisida baru turunan ftalamida yang mengandung hidrazon (FMH) menggunakan metode regresi multilinear (MLR), regresi komponen utama (PCR) dan jaringan syaraf tiruan (JST). Ada lima deskriptor yang masuk dalam model MLR dan JST, dan lima variabel laten yang diperoleh dari analisis PCA yang digunakan dalam analisis PCR. Perhitungan deskriptor dilakukan menggunakan metode semiempirik PM6. Hasil penelitian menunjukkan analisis JST merupakan metode statistik paling baik yang ditunjukkan oleh nilai koefisien korelasi deskriptor dan aktivitas yang relatif tinggi $\left(r^{2}=0,84\right)$. Berdasarkan model yang diperoleh, telah dilakukan desain beberapa insektisida baru yang mempunyai aktivitas prediksi yang lebih tinggi dari senyawa yang telah disintesis sebelumnya yaitu 2-(Dekalinkarbamoil)-5-kloro-N'-((5metiltiopen-2-il)metilen)benzohidrazid, 2-(Dekalinkarbamoil)-5-kloro-N'-((tiopen-2-yl)-metilen)benzohidrazid dan 2(Dekalinkarbamoil)-N'-(4-fluorobenzilidin)-5-klorobenzohidrazid dengan nilai log LC $C_{50}$ masing-masing sebesar 1,640, 1,672 dan 1,769 .

Kata Kunci: HKSA; ftalamida; hidrazon; semiempirik; regresi multilinear; regresi komponen utama; jaringan syaraf tiruan

\section{INTRODUCTION}

Computational Chemistry has grown so rapidly in last two decades mainly due to its application in helping to design molecules in silico. Computational chemistry methods most widely used so far is the Quantitative Structure Activity Relationship (QSAR). This method is useful in understanding how chemical structure relates to the biological activity and the toxicity of natural and synthetic chemicals like pesticides. The use of QSAR method have been reported by Mudasir et al. [1-2] who studied the structure-activity relationships of organophosphate insecticides and fungicides derived from 1,2,4-Tiadizolin.

\footnotetext{
* Corresponding author. Tel/Fax : +62-85743340277
}

Email address : putra_4d88@yahoo.com

Adi Syahputra et al. 
Table 1. Insecticidal activities of $\mathrm{PCH}$ derivatives [4]

\begin{tabular}{|c|c|c|c|c|}
\hline \multirow{2}{*}{ Compound } & \multicolumn{2}{|l|}{ Substituent type } & \multirow{2}{*}{$\begin{array}{c}\mathrm{LC}_{50} \\
\text { (mg/L) }\end{array}$} & \multirow{2}{*}{$\log L C_{50}$} \\
\hline & $\mathrm{Ar}$ & $\mathbf{R}$ & & \\
\hline 1 & 2-chlorophenyl & isopropyl & 170.664 & 2.232 \\
\hline 2 & 2-chlorophenyl & cyclohexyl & 148.396 & 2.171 \\
\hline 3 & 2-fluorophenyl & butyl & 121.941 & 2.086 \\
\hline 4 & 2-fluorophenyl & cyclohexyl & 276.113 & 2.441 \\
\hline 5 & 4-fluorophenyl & isopropyl & 68.005 & 1.833 \\
\hline 6 & 4-fluorophenyl & butyl & 309.938 & 2.491 \\
\hline 7 & 4-(trifluoromethyl)phenyl & butyl & 130.043 & 2.114 \\
\hline 8 & 4-hydroxyphenyl & isopropyl & 128.575 & 2.109 \\
\hline 9 & 4-hydroxyphenyl & cyclohexyl & 244.229 & 2.388 \\
\hline 10 & 2-furanyl & isopropyl & 161.476 & 2.208 \\
\hline 11 & 2-furanyl & butyl & 234.069 & 2.369 \\
\hline 12 & 2-furanyl & cyclohexyl & 221.334 & 2.345 \\
\hline 13 & 2-methyl-5-furanyl & isopropyl & 121.636 & 2.085 \\
\hline 14 & 2-methyl-5-furanyl & cyclohexyl & 271.415 & 2.434 \\
\hline 15 & 2-thienyl & isopropyl & 70.515 & 1.848 \\
\hline 16 & 2-thienyl & butyl & 124.039 & 2.094 \\
\hline 17 & 2-thienyl & cyclohexyl & 113.217 & 2.054 \\
\hline 18 & 3-methyl-2-thienyl & isopropyl & 124.447 & 2.095 \\
\hline 19 & 3-methyl-2-thienyl & cyclohexyl & 58.903 & 1.770 \\
\hline 20 & 5-methyl-2-thienyl & isopropyl & 76.178 & 1.882 \\
\hline 21 & 5-chloro-3-methyl-1-phenyl-1H-pyrazol-4-yl & cyclohexyl & 266.287 & 2.425 \\
\hline
\end{tabular}<smiles></smiles>

Fig 1. Chemical structure of $\mathrm{PCH}$

This method can be use to help in searching new insecticides with maximum activity against insect pest. Research to obtain a new insecticide is highly required with respect to the phenomenon of insecticide-resistant cases of insect pests [3]. One type of insecticide that has the potential to be developed is phthalamide derivatives containing hydrazone $(\mathrm{PCH})$. This insecticide has been used against Myzus persicae [4]. Action mechanism of these compounds is similar to flubendiamide, which is active in the calcium release channel (ryanodine receptors, RyR) in insects [5] and has the impact on the modulation of of RyR on $\mathrm{Ca}^{2+}$ pump [6]. The compound caused several symptoms such as gradual contraction, thickening and shortening of the insect body without convulsions immediately after treatment, which can be clearly distinguished from the symptoms caused by conventional insecticides [7].

In this study, QSAR model of phthalamide insecticides is derived from the data set of chemical structure and biological activities using multiple linear regressions (MLR and PCR) as well as artificial neural network (ANN) methods. The best models obtained from these methods were used to predict the biological activity of new designed insecticides of $\mathrm{PCH}$ derivatives.

Specifically, the purpose of this study was to determine the physicochemical properties (descriptors) of the compounds that influence the insecticidal activity of $\mathrm{PCH}$ derivatives. The widely used calculation of descriptors is AM1 and PM3. In this study, we used semi-empirical PM6 method for the calculation of descriptors. This method was selected because of inadequate and the calculation is more accurate in terms of the core-core interactions and hydrogen bonding [8].

\section{MATERIAL AND METHODS}

\section{Data Set}

$\mathrm{PMH}$ derivatives insecticides were taken from literature [4]. Lethal concentration values, represented as $\mathrm{LC}_{50}$ were used as the dependent variable. The lethal concentration fifty $\left(\mathrm{LC}_{50}\right)$ was expressed in milligram of toxicant per liter of body weight (see Table 1).

\section{Instrumentation}

For this study, a PC equipped with Intel ${ }^{\circledR}$ Dual Core Processor $2.66 \mathrm{GHz}$; RAM 2 GB and HDD $320 \mathrm{~GB}$ 
Table 2. Statistical parameters of 10 selected QSAR models of PCH derivatives of training-set compounds

\begin{tabular}{|c|c|c|c|c|c|c|}
\hline Model & $\begin{array}{l}\text { Descriptors } \\
\end{array}$ & $\mathbf{n}$ & $\mathbf{r}$ & $r^{2}$ & SE & $\mathbf{F}_{\mathrm{cal}} / \mathbf{F}_{\mathrm{tab}}$ \\
\hline 1 & $\begin{array}{l}q_{4}, q N_{1}, q C_{5}, S A, \log P, q O_{1}, q C_{2}, M D, q C_{3}, E_{L U M O} \\
q C_{6}, q C l, q C_{1}, q N_{3}\end{array}$ & 16 & 0.997 & 0.995 & 0.062 & 0.054 \\
\hline 2 & $\begin{array}{l}\mathrm{qC}_{4}, \mathrm{qN}_{1}, \mathrm{qC}_{5}, \mathrm{SA}, \log \mathrm{P}, \mathrm{qO}_{1}, \mathrm{qC}_{2}, \mathrm{MD}, \mathrm{qC}_{3}, \mathrm{E}_{\mathrm{LUMO}} \text {, } \\
\mathrm{qC}_{6}, \mathrm{qCl}, \mathrm{qN}_{3}\end{array}$ & 16 & 0.996 & 0.993 & 0.052 & 1.067 \\
\hline 3 & $\begin{array}{l}\mathrm{qC}_{4}, \mathrm{qN}_{1}, \mathrm{qC}_{5}, \mathrm{SA}, \log \mathrm{P}, \mathrm{qO}_{1}, \mathrm{qC}_{2}, \mathrm{MD}, \mathrm{qC}_{3}, \mathrm{E}_{\mathrm{LUMO}}, \\
\mathrm{qCl}, \mathrm{qN}_{3}\end{array}$ & 16 & 0.994 & 0.988 & 0.053 & 2.436 \\
\hline 4 & $\begin{array}{l}q \mathrm{C}_{4}, q N_{1}, q C_{5}, S A, \log P, q O_{1}, q C_{2}, q C_{3}, E_{L U M O}, q C l \text {, } \\
q N_{3}\end{array}$ & 16 & 0.987 & 0.974 & 0.068 & 2.329 \\
\hline 5 & $\mathrm{qC}_{4}, \mathrm{qN}_{1}, \mathrm{qC}_{5}, \mathrm{SA}, \log \mathrm{P}, \mathrm{qO}_{1}, \mathrm{qC}_{2}, \mathrm{qC}_{3}, \mathrm{E}_{\mathrm{LUMO}}, \mathrm{qN}_{3}$ & 16 & 0.977 & 0.955 & 0.081 & 2.244 \\
\hline 6 & $\mathrm{qC}_{4}, \mathrm{qN}_{1}, \mathrm{qC}_{5}, \log \mathrm{P}, \mathrm{qO}_{1}, \mathrm{qC}_{2}, \mathrm{qC}_{3}, \mathrm{E}_{\mathrm{LUMO}}, \mathrm{qN}_{3}$ & 16 & 0.972 & 0.945 & 0.082 & 2.788 \\
\hline 7 & $\mathrm{qC}_{4}, \mathrm{qN}_{1}, \log \mathrm{P}, \mathrm{qO}_{1}, \mathrm{qC}_{2}, \mathrm{qC}_{3}, \mathrm{E}_{\mathrm{LuMO}}, \mathrm{qN}_{3}$ & 16 & 0.957 & 0.916 & 0.093 & 2.553 \\
\hline 8 & $\mathrm{qC}_{4}, \mathrm{qN}_{1}, \log \mathrm{P}, \mathrm{qO}_{1}, \mathrm{qC}_{2}, \mathrm{qC}_{3}, \mathrm{E}_{\mathrm{LUMO}}$ & 16 & 0.944 & 0.891 & 0.099 & 2.678 \\
\hline 9 & $\mathrm{qC}_{2}, \mathrm{E}_{\mathrm{LUMO}}, \mathrm{qC}_{4}, \mathrm{qN}_{1}, \mathrm{qO}_{1}, \log \mathrm{P}$ & 16 & 0.910 & 0.828 & 0.117 & 3.374 \\
\hline 10 & $\mathrm{E}_{\text {LUMO }}, \mathrm{qC}_{4}, \mathrm{qN} \mathrm{N}_{1}, \mathrm{qO}_{1}, \log \mathrm{P}$ & 16 & 0.885 & 0.784 & 0.125 & 3.326 \\
\hline
\end{tabular}

Table 3. Comparison between predicted and observed values of insecticidal activity for 5 compounds of test set calculated by 9 selected candidate QSAR models

\begin{tabular}{|c|c|c|c|c|c|c|c|c|c|}
\hline \multirow{2}{*}{$\begin{array}{l}\text { Observed } \\
\text { log LC }{ }_{50}\end{array}$} & \multicolumn{9}{|c|}{ Predicted log $\mathrm{LC}_{50}$} \\
\hline & 2 & 3 & 4 & 5 & 6 & 7 & 8 & 9 & 10 \\
\hline 2.109 & 2.379 & 2.274 & 2.615 & 2.506 & 2.192 & 2.171 & 2.184 & 2.199 & 2.165 \\
\hline 2.369 & 2.304 & 2.192 & 2.535 & 2.569 & 2.390 & 2.178 & 2.159 & 2.361 & 2.392 \\
\hline 1.848 & 2.112 & 1.933 & 2.268 & 2.157 & 1.908 & 1.908 & 1.879 & 1.803 & 1.861 \\
\hline 2.095 & 1.759 & 1.656 & 1.944 & 1.890 & 1.601 & 1.552 & 1.525 & 1.489 & 1.502 \\
\hline 2.425 & 3.169 & 2.871 & 3.300 & 3.091 & 2.890 & 2.936 & 2.911 & 2.941 & 2.982 \\
\hline PRESS & 0.812 & 0.454 & 1.248 & 0.778 & 0.471 & 0.601 & 0.612 & 0.643 & 0.078 \\
\hline
\end{tabular}

was used. The software programs extensively used in this study were Gaussian ${ }^{\circledR} 09 \mathrm{~W}$, HyperChem ${ }^{T M}$ 8.0.10, statistical programs IBM $^{\circledR}$ SPSS ${ }^{\circledR}$ Version 19 and MATLAB 7.0.1.

\section{Method}

\section{Calculation of descriptors}

Descriptors used in this study were electronic parameters, e.g. atomic net-charge (q), moment dipole $(\mu)$, highest occupied molecular orbital (HOMO) and lowest unoccupied molecular orbital (LUMO) energy as well as molecular parameters, i.e. partition coefficient $(\log P)$, refractivity $(R)$, polarizability, molecular weight $(\mathrm{MW})$, surface area (SA), volume (V) and hydration energy (HE). Electronic parameters were taken from log file of the optimized structure of insecticides (Fig. 1) using semiempirical PM6 method within G09W package. Molecular parameters were calculated using Hyperchem package software.

\section{Model development}

Multiple linear regression. QSAR models derived from MLR analysis was done by making regression analysis between descriptors and log $\mathrm{LC}_{50}$ directly using the backward method in SPSS version 19. Before analysis, the data were separated into training data and test data, consisting of 16 and 5 compounds, respectively. The regression analysis was done according to the following linear equation:

$\log L C_{50}=\alpha+\beta_{1} X_{1}+\ldots+\beta_{i} X_{i}+\varepsilon$

Equation (1) represents the general QSAR equation model. The symbol $\alpha$ and $\beta$ in the equations stand for a constant and fitting coefficient of corresponding descriptors $(X)$, respectively and $\varepsilon$ is error.

Principle component regression. QSAR models in PCR analysis obtained by regressing insecticidal activity with latent variables resulting from Principle Component Analysis (PCA). PCA technique is useful in summarizing the information from the structure and also help in understanding the distribution of the compound. PCA analysis was evaluated using SPSS version 19. MLR between latent variables and log $L C_{50}$ was conducted similar to MLR analysis process in equation (1).

Generation QSAR model using Artificial Neural network (ANN) analysis. ANN analysis was evaluated using Matlab 7.0.1 program. In general, to build the network three-layers were required, i.e. input layer, hidden layer and output layer [9]. Input consisted of a number of descriptors used. The number of neurons in the hidden layer was set during the experiment. One neuron in the output contains the sigmoid activation function. Separation of training and test data was carried out in the same way as for MLR analysis. For learning neural network system, the data of the insecticidal activity of 16 compounds of $\mathrm{PCH}$ derivatives 
Table 4. Statistical parameters of 5 selected QSAR models of PCH derivatives generated by PCR analysis

\begin{tabular}{cccccc}
\hline Model & Descriptors & $\mathbf{r}$ & $\mathbf{r}^{2}$ & $\mathbf{S E}$ & $\mathbf{F}_{\text {cal }} / \mathbf{F}_{\text {tab }}$ \\
\hline 1 & $\mathrm{~T}_{5}, \mathrm{~T}_{4}, \mathrm{~T}_{3}, \mathrm{~T}_{2}, \mathrm{~T}_{1}$ & 0.521 & 0.271 & 0.214 & 0.385 \\
2 & $\mathrm{~T}_{4}, \mathrm{~T}_{3}, \mathrm{~T}_{2}, \mathrm{~T}_{1}$ & 0.521 & 0.271 & 0.207 & 0.496 \\
3 & $\mathrm{~T}_{3}, \mathrm{~T}_{2}, \mathrm{~T}_{1}$ & 0.506 & 0.256 & 0.203 & 0.609 \\
4 & $\mathrm{~T}_{2}, \mathrm{~T}_{1}$ & 0.450 & 0.202 & 0.204 & 0.642 \\
5 & $\mathrm{~T}_{2}$ & 0.382 & 0.146 & 0.206 & 0.741 \\
\hline
\end{tabular}

(training-set compounds) were used. ANN models were designed and trained using these data. The training-set data were used in the ANN learning to recognize the relationship between input and output. Finally, the testing-set data consisting of five compounds were prepared to validate the obtained model from the ANN training before it was being applied to predict the activity of new designed insecticides.

Design of new compounds. The new compounds of $\mathrm{PCH}$ insecticides was designed with the guidance of the best QSAR model obtained to maximize activity of the designed compounds compared to those previously has been synthesized. In designing new compounds, we refer to the some synthesized compounds which experimentally have been proven to exhibit high activity, i.e. compounds number 5, 15, 19 and 20 in Table 1. The design of the new molecules was focused on altering substituents $R$ and $A r$ and considering the availability of precursors/reagents so that the obtained new molecules will be possible to be synthesized in laboratory.

\section{RESULT AND DISCUSSION}

\section{Multiple Linear Regression Analysis}

To obtain the best QSAR model that correlates independence variables and dependence variable, multiple linear regression analysis using SPSS software has been performed. All variables were included in the model set-up. At the first step, all variables are included in the model and the less relevant variables were eliminated from the model by backward method automatically. This procedure finally gives 10 candidates of QSAR models as listed in Table 2. It is immediately emerged from Table 2, that all selected models show a good correlation $(r \approx 0.9)$ between biological activity and selected descriptors in the fitting process. Selection of models are based on the statistical parameters such as correlation coefficient $(r)$, coefficient of determination $\left(r^{2}\right)$, the calculation error ( $S E)$ and significance of the model $\left(F_{\text {cal }} / F_{\text {tab }}\right)$. It is clearly shown that one of the ten candidate models have value of $F_{\mathrm{cal}} / F_{\mathrm{tab}}$ less than 1 , therefore the model is automatically rejected and does not included in the model validation.

Further selection of the model is done by looking at the ability of the model to predict the activity of five test compounds, i.e. insecticide compounds which are not included in the model building. The best model is chosen from those giving predictive activity close to the insecticidal activity of experimental results as shown by their PRESS (predictive residual sum of square) given in Table 3. Based on the value of the PRESS, it is evidenced that model-10 gives the smallest PRESS value; therefore this model is finally selected as the best MLR QSAR model.

\section{Principle Component Regression Analysis}

In this study, PCA method is used to obtain the latent variables from all possible original descriptors/variables, e.g. electronic and molecular variables, for 21 compounds of $\mathrm{PCH}$ derivatives prior to PCR analysis using SPSS. From PCA analysis, five components of the matrix (latent variables) are obtained, giving total information of representation variants as much as $90.313 \%$. The percentage contribution of each component to the total information of representation variants is $37.981 ; 22.309 ; 16.295$; 8.302 and 5.426 for the components F1, F2, F3, F4 and $\mathrm{F} 5$, respectively.

By using latent variables, QSAR models has been generated using PCR analysis that correlate independence variables (five latent variables) and dependence variable (log $\mathrm{LC}_{50}$ ) within SPSS software package. At the beginning, all latent variables are included in the model and then the variables which have weak correlation with insecticidal activity will be gradually excluded from the model by backward method. From the PCR analysis, five models were obtained as listed in Table 4. However, no single model is satisfied from the statistical points of view because the correlation coefficient $(r)$ between log $L_{50}$ and activity is considerably small $(<0.521)$ and furthermore, the significance of the five models is also very low, i.e. less than $95 \%$ as can be seen from their $F_{\text {cal }} / F_{\text {tab }}$ values which are lower than unity. Thus, all PCR QSAR models are not adequate and automatically eliminated for further model validation.

\section{Artificial Neural Network Analysis}

QSAR model generated by artificial neural network (ANN) analysis has been done by using selected descriptors that has been obtained from 
Table 5. Comparison between predicted and observed values of insecticide activity obtained from ANN analysis

\begin{tabular}{ccc}
\hline \multirow{2}{*}{ Compound } & \multicolumn{2}{c}{ log $\mathbf{L C}_{\mathbf{5 0}}$} \\
\cline { 2 - 3 } & observed & predicted \\
\hline Training set & & \\
1 & 2.232 & 2.218 \\
2 & 2.171 & 2.169 \\
3 & 2.086 & 2.102 \\
4 & 2.441 & 2.382 \\
5 & 1.833 & 1.898 \\
6 & 2.491 & 2.414 \\
7 & 2.114 & 2.123
\end{tabular}

\begin{tabular}{rrr}
9 & 2.388 & 2.343 \\
10 & 2.208 & 2.207 \\
12 & 2.345 & 2.300 \\
13 & 2.085 & 2.100 \\
14 & 2.434 & 2.379 \\
16 & 2.094 & 2.086 \\
17 & 2.054 & 2.094 \\
19 & 1.770 & 1.850 \\
20 & 1.882 & 1.938 \\
$r$ & & 0.997 \\
$r^{2}$ & & 0.929 \\
\hline
\end{tabular}

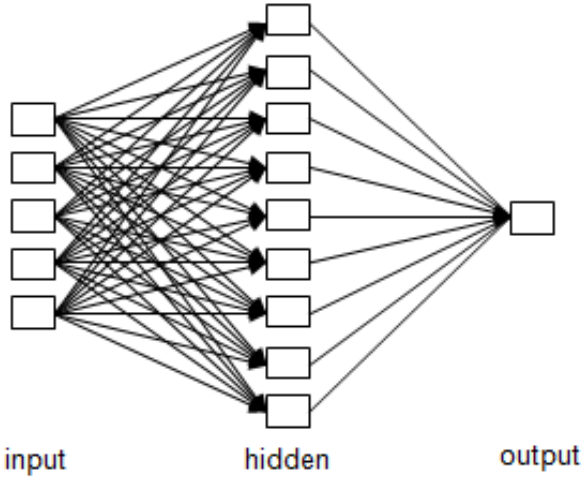

Fig 2. The best ANNs architecture (5-9-1)

previous MLR analysis as an input. The training set of data is needed in ANN to help the system learn and recognize the relationship between the input and output data. Similar to those used in MLR and PCR analysis, five compounds of insecticides are randomly separated and used as testing-set compounds to validate the ANN model prior to the application of the network in predicting the activity of new designed insecticides.

From the ANN analysis, it is revealed that the best architecture of neural network is 5-9-1 pattern as illustrated in Fig. 2 with optimum learning rate of 0.2 and 5000 iterations operated on Matlab 7.0.1 for Windows ${ }^{\mathrm{TM}}$. Results of ANN analysis indicates a strong relationship between descriptors and log $L C_{50}$. The plot of observed and calculated values for the training and test set of insecticide compounds has linear regression coefficient (r) of 0.997 and 0.977 respectively as listed in Table 5 . Clearly, it has been demonstrated that artificial neural network results give the best result in building the quantitative structure activity relationship models of $\mathrm{PCH}$ insecticides. These results suggest that the relationship between chemical structure this class of insecticides and their biological activity is better to be approached using non-linear function.

\section{Analysis of Structure-Activity Relationship}

Structure and activity relationship of $\mathrm{PCH}$ derivatives that has been obtained may be explained with respect to the number of electronic and hydrophobic descriptors involved. It has been known that electronic and structural properties as well as hydrophobicity of the compounds are important factors governing the protein-ligand interaction [10]. These parameters are of critical importance in determining the types of intermolecular forces that underlie drugreceptor interactions [11]. In this study, electronic descriptors as defined by net-atomic charges (q) and $\mathrm{E}_{\text {LUMO }}$ energy is important in describing the electronic interaction and reactivity of these biologically active molecules. Hydrophobic parameters play an essential role with respect to the ability of the molecule to penetrate the membrane cell [12] and it is directly related to the solubility of the compounds in aqueous phases, to their ability to pass membrane permeation, and to its (merely entropic) contribution to ligand binding at the receptor site [13]. Hydrophobic descriptor which is commonly expressed by $\log P$ is also an important parameter to describe transport of the compound to the target. 
Table 6. Comparison between observed and predicted values of insecticide activity calculated by selected model of MLR and ANN together with their values of pred_$r^{2}$ and $r_{m}^{2}$

\begin{tabular}{|c|c|c|c|c|c|c|}
\hline \multirow{2}{*}{$\begin{array}{l}\text { Observed } \\
\log L C_{50}\end{array}$} & \multicolumn{6}{|c|}{ Predicted log LC 50} \\
\hline & MLR & pred_ $r^{2}$ & $r_{m}^{2}$ & ANN & pred_ $r^{2}$ & $r_{m}^{2}$ \\
\hline 2.425 & 2.982 & & & 2.425 & & \\
\hline 2.369 & 2.392 & & & 2.331 & & \\
\hline 2.109 & 2.165 & 0.0779 & 0.3065 & 2.122 & 0.9201 & 0.7961 \\
\hline 2.095 & 1.502 & & & 1.858 & & \\
\hline 1.848 & 1.861 & & & 1.849 & & \\
\hline
\end{tabular}

Table 7. New designed PCH insecticide molecules and predicted log $\mathrm{LC}_{50}$ calculated using the best QSAR model

\begin{tabular}{|c|c|c|c|}
\hline \multirow{2}{*}{ Compd } & \multicolumn{2}{|c|}{ Substituent type } & \multirow{2}{*}{$\begin{array}{c}\text { Predicted } \\
\log L_{5} \\
\end{array}$} \\
\hline & $\mathrm{Ar}$ & $\mathbf{R}$ & \\
\hline 22 & 4-bromophenyl & isopropyl & 2.208 \\
\hline 23 & 4-bromophenyl & cyclohexyl & 2.000 \\
\hline 24 & 4-bromophenyl & neopentyl & 2.657 \\
\hline 25 & 4-bromophenyl & decaline & 4.006 \\
\hline 26 & 4-fluorophenyl & neopentyl & 2.431 \\
\hline 27 & 4-fluorophenyl & methyl & 1.993 \\
\hline 28 & 4-fluorophenyl & decaline & 1.769 \\
\hline 29 & 2,3,5,6-fluorophenyl & neopentyl & 2.121 \\
\hline 30 & $2,3,5,6$-fluorophenyl & methyl & 3.071 \\
\hline 31 & 2,3,5,6-fluorophenyl & isopropyl & 2.084 \\
\hline 32 & $2,3,5,6$-fluorophenyl & isobutyl & 2.114 \\
\hline 33 & $2,3,5,6$-fluorophenyl & cyclohexyl & 2.071 \\
\hline 34 & 2,3,5,6-fluorophenyl & decaline & 3.112 \\
\hline 34 & 4-chlorophenyl & neopentyl & 2.669 \\
\hline 35 & 4-chlorophenyl & decaline & 2.905 \\
\hline 37 & 2-thienyl & decaline & 1.672 \\
\hline 38 & 2-thienyl & methyl & 2.012 \\
\hline 39 & 2-thienyl & neopentyl & 1.790 \\
\hline 40 & pyridine & cyclohexyl & 3.980 \\
\hline 41 & pyridine & isopropyl & 2.521 \\
\hline 42 & pyridine & methyl & 2.384 \\
\hline 43 & pyridine & decaline & 2.425 \\
\hline 44 & 3-methyl-2-thienyl & decaline & 2.095 \\
\hline 45 & 3-methyl-2-thienyl & neopentyl & 1.705 \\
\hline 46 & 3-methyl-2-thienyl & phenyl & 2.095 \\
\hline 47 & 5-methyl-2-thienyl & decaline & 1.640 \\
\hline 48 & 5-methyl-2-thienyl & methyl & 2.042 \\
\hline 49 & 5-methyl-2-thienyl & neopentyl & 1.785 \\
\hline
\end{tabular}

\section{Model Validation}

In this study, we need to compare the QSAR models obtained from MLR and ANN analysis in order to determine which one is the best model. The statistical parameters used for this purpose are pred_r $r^{2}$

and $r_{m}^{2}$. The pred $r^{2}$ parameter is determined on the basis of the following equation (2).

$$
\text { pred_r } r^{2}=1-\frac{\sum\left(y_{i}-y_{i}\right)^{2}}{\sum\left(y_{i}-y_{\text {mean }}\right)^{2}}
$$

where $y_{i}$, and $y_{\wedge_{i}}$ are respectively the experimental and predicted activity of the $i^{\text {th }}$ molecule in the test set. $y_{\text {mean }}$ is the average activity of all molecules in the training set. The pred_r $r^{2}$ value of greater than 0.5 is an indicator of good external predictability [14].

The parameter $r_{m}^{2}$ is determined by the following equation (3).

$r_{m}^{2}=r^{2}\left(1-\sqrt{\left|r^{2}-r_{0}^{2}\right|}\right)$

where $r^{2}$ and $r_{0}^{2}$ respectively are the determination coefficient of the plot between the observed and predicted activities of the test set compounds calculated with and without intercept. In general, $r^{2}$ and $r_{0}^{2}$ would not differ significantly, and an $r_{m}^{2}$ value of greater than 0.5 is an indicator of good external predictability [15]. By examining Table 6 , it can be 
concluded that ANN QSAR model is the best model because it gives the statistical parameters of pred_ $r^{2}$ and $r_{m}^{2}$ higher than those of MLR method. Detailed results of pred_ $r^{2}$ and $r_{m}^{2}$ calculation are presented at in Table 6 . Based on these results, for further study, therefore, ANN QSAR model is used as guidance in designing new insecticide of the class.

\section{Design of New Insecticide}

The design of new insecticide of $\mathrm{PCH}$ derivatives has been done on the basis of the best QSAR model obtained and this equation model was then used to predict their activity. In designing the structure of the new insecticide molecule, $\mathrm{R}$ and $\mathrm{Ar}$ substituents attached to the main structure were modified so that the higher insecticide activity of the new designed molecule compared to that of the previously synthesized molecules was achieved.

For that purposes, $\mathrm{R}$ of electron donating substituent has been selected to examine the influence of electron distribution in the phenyl ring on insecticide activity. Furthermore, variation of substituent at this position will also influence the polarity of the molecule. On the other hand, replacing Ar substituent with electron withdrawing moeties is expected to give impact on the electronegativity of the compound, resulting in high activity of the molecule. Table 7 lists the detailed structure/substituent of new insecticide molecule that have been designed on the basis of the above assumption along with their predicted activity values calculated using the best QSAR model.

In this study, R has been replaced using more and less bulkier substituent to evaluate the effect of electron resonance and polarization on the insecticide activity. The evaluation was done by comparing the predicted log $\mathrm{LC}_{50}$ values of the corresponding compounds. Results of the study show that there is a significant difference in the value of predicted log $L_{50}$ when $R$ is varied and $\mathrm{Ar}$ substituent is kept the same. For example, compound number 47 where $R$ is decaline, the bulkier substituent has predicted log $L_{50}$ of 1.640 while compound 48 with $\mathrm{R}=$ methyl, less bulk substituent has predicted log $\mathrm{LC}_{50}$ of 2.042. This result indicates that bulkier substituent enhances electron resonance so that the electron is more distributed on the phenyl ring, resulting in the higher solubility of the compound.

The effect of electron withdrawing substituent at $\mathrm{Ar}$ position on the value of predicted activity has also been investigated. Replacement of fluorine atom with bromine where substitueny $\mathrm{R}$ kept constant has significant effect on their predicted activity due to the differences in their electronegativity. As clearly seen in Table 7, compound number $24(\mathrm{Ar}=4$-bromophenyl) and $28(\mathrm{Ar}=4-$ fluorophenyl) have predicted log $\mathrm{LC}_{50}$ of 4.006 and 1.769 respectively. This suggests that more electronegative substituent at Ar position increases the activity of the molecule.

\section{CONCLUSION}

It has been demonstrated that semi-empirical PM6 is good computational method for the calculation of descriptors in QSAR analysis of $\mathrm{PCH}$ derivatives such as electronic and hydrophobic parameters. From QSAR equation model, it is revealed that electronic and hydrophobic descriptors have significant contribution to the insecticidal activity. The existence of non-linear relationship between chemical structure and biological activity of $\mathrm{PCH}$ derivatives is indicated by the best statistical parameters of non-linear QSAR model generated by ANN analysis. It is, therefore, clearly shown that ANN analysis can be an alternative approach when the relationship between activity and descriptors could not be well fitted using the linear regression analysis. Based on the best QSAR model obtained, it has been designed some new insecticide compounds which have predicted insecticidal activities higher than those of the existing compounds. This new designed compounds are suggested to be further synthesized and then tested for their insecticidal activity in the laboratory.

\section{ACKNOWLEDGEMENT}

First Author thanks to Lembaga Pengelola Dana Pendidikan (LPDP), Ministry of Finance, The Republic of Indonesia for financial support.

\section{REFERENCES}

1. Mudasir, Tahir, I., and Putri, I.P.A.M., 2003, Indo. J. Chem., 3 (1), 39-47.

2. Mudasir, Wibowo, Y.M., and Pranowo, H.D., 2013, Indo. J. Chem., 13 (1), 86-93.

3. Insecticide Resistance Action Committee, 2012, $47^{\text {th }}$ Meeting of IRAC International, Indianapolis.

4. Liu, M., Wang, Y., Wangyang, W-Z., Liu, F., Cui, YL., Duan, Y-S., Wang, M., Liu, S-Z., and Rui, C-H., 2010, J. Agric. Food Chem., 58 (11), 6858-6863.

5. Ebbinghaus-Kintscher, U., Lümmen, P., Raming, K., Masaki, T., and Yasokawa, N., 2007, Pflanzenschutz-Nachrichten Bayer, 60 (2), 117140.

6. Masaki, T., Yasokawa, N., Fujioka, S., Motoba, K., Tohnishi, M., and Hirooka, T., 2009, J. Pestic. Sci., 34 (1), 37-42.

7. Masaki, T., Yasokawa, N., Tohnishi, M., Nishimatsu, T., Tsubata, K., Inoue, K., Motoba, K., 
and Hirooka, T., 2006, Mol. Pharmacol., 69 (5), 1733-1739.

8. Stewart, J.J.P., 2007, J. Mol. Model., 13 (12), 11731213.

9. Hu, Y.H., and Jenq-Neng, H., 2002, Handbook of Neural Network Signal Processing, CRC Press, Florida.

10. Akamatsu, M., 2011, J. Agric. Food Chem., 59 (7), 2909-2917.

11. Abraham, D.J., 2003, Burger's Medicinal Chemistry and Drug Discovery $6^{\text {th }}$ ed., John Wiley \& Sons, California.
12. Rekker, R.F., 1986, Lecture Course QSAR, Mid Cancer Training in Pharmacochemistry, Faculty of Pharmacy UGM and Department of Pharmacochemistry Vrise Universities, Yogyakarta.

13. Kubinyi, H., 1993, QSAR: Hansch Analysis and Related Approaches, VCH Verlagsgesellshaft, Weinhem.

14. Sahu, K.N., Sharma, M., Mourya, V., and Kohli, D.V., 2012, Acta Pol. Pharm., 69 (6), 1153-1165.

15. Hu, R., Doucet, J.P., Delamar, M., and Zhang, R., 2009, Eur. J. Med. Chem., 44 (5), 2158-2171. 